\title{
Complicated Crown Fracture: A Case Report
}

\author{
Rivail Antonio Sergio FIDEL ${ }^{1,2}$ \\ Ricardo Guimarães de CARVALHO ${ }^{1}$ \\ Cláudio Herdy VARELA ${ }^{1}$ \\ Ariadne LETRA ${ }^{3}$ \\ Sandra Rivera FIDEL ${ }^{1,2}$ \\ ${ }^{1}$ Faculty of Dentistry, Unigranrio, Rio de Janeiro, RJ, Brazil \\ ${ }^{2}$ Faculty of Dentistry, State University of Rio de Janeiro (UERJ), Rio de Janeiro, RJ, Brazil \\ ${ }^{3}$ Department of Biological Sciences, Faculty of Dentistry of Bauru (FOB), University of São Paulo, Bauru, SP, Brazil
}

\begin{abstract}
This case report describes the treatment of a severe crown fracture of an immature mandibular permanent incisor in a 12 year-old boy referred to the Dental Traumatology Center of UNIGRANRIO University. After conventional endodontic procedures and dressing with calcium hydroxide, an apical plug was made with mineral trioxide aggregate in order to avoid an overflow of gutta-percha and endodontic sealer into the periapical tissues. Two years later, the tooth was clinically asymtomatic and radiographs showed total repair of the apical lesion.
\end{abstract}

Key Words: traumatic injury, calcium hydroxide, periapical lesion.

\section{INTRODUCTION}

Traumatic injuries to immature permanent teeth represent a serious endodontic challenge. If the pulp becomes necrotic, pulpectomy and root canal therapy will be the treatment of choice. If the root apex is not completely formed, obturation becomes an extremely difficult procedure, especially when thermoplasticized gutta-percha is used.

Apexification with calcium hydroxide has become the standard treatment choice to provide an apical stop and avoid possible overfilling (1). The main purpose of apexification is to induce the formation of a mineralized barrier at the apex so that the obturation materials do not get thrown into the periapical tissues (2). However, it is a very time-consuming procedure (3).

Mineral Trioxide Aggregate (MTA) has been indicated as a suitable material for apexification of immature roots based on its ability of inducing hard tissue formation. Several studies have reported its excellent biocompatibility, sealing ability and mechanical properties as apical sealing material. In addition, its relatively fast setting time makes MTA a reliable material to be used as a plug in cases of open apexes, in a singlestep procedure, whereas treatment with calcium hydroxide may take months (4).

This case report describes the treatment of a severe crown fracture of an immature mandibular permanent incisor in a 12 year-old boy referred to the Dental Traumatology Center of UNIGRANRIO University by means of conventional endodontic procedures, calcium hydroxide dressing and apical plug with mineral trioxide aggregate.

\section{CASE REPORT}

A 12-year-old boy was referred to the Dental Traumatology Center of Unigranrio University (Rio de Janeiro, Brazil) for the treatment of the mandibular left lateral incisor. The patient reported to have fallen 4 years before and that no treatment had been performed until that moment. He also referred painful symptomatology in the area and formation of a sinus tract on the buccal region adjacent to the tooth. Clinical examination revealed

Correspondence: Dr. Rivail Antonio Sergio Fidel, Rua Otavio Kelly, 63, apto. 301, Tijuca, 20511-280 Rio de Janeiro, RJ, Brasil. Tel: +5521-2587-6455. Fax: +55-21-2568-3056. e-mail: rivail@uerj.br 
a complicated crown fracture and mobility of the mandibular left lateral incisor. Edema and a sinus tract were also associated. In addition, the tooth failed to respond to thermal or eletric pulp testing.

Periapical radiographs demonstrated an incompletely formed root apex and a large radiolucent area (Fig. 1). With a rubber dam in place and after access opening, root canal instrumentation was performed using a crown-down technique. The working length was established at $1 \mathrm{~mm}$ short of the radiographic apex. Copious irrigation with $2.5 \%$ sodium hypochlorite was done throughout cleaning and shaping procedures. The canal was dressed with a calcium hydroxide paste (PMCC, SS White Artigos Dentários Ltda., Rio de

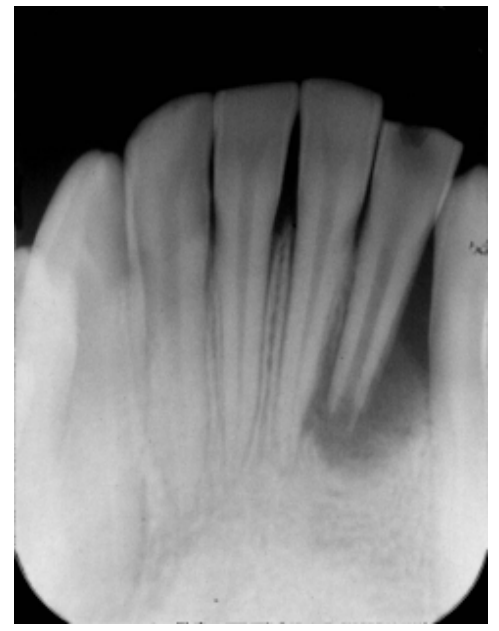

Figure 1. Preoperative radiograph showing mandibular left lateral incisor and large periapical lesion associated.

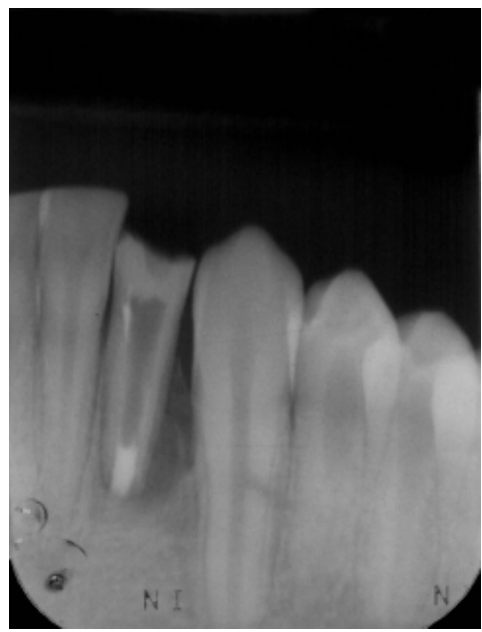

Figure 3. Radiograph showing the apical plug of MTA.
Janeiro, RJ) (Fig. 2) and the access cavity sealed with a temporary glass ionomer cement (SSWhite). Calcium hydroxide dressing was changed at 3-month intervals over 1 year. Radiographic examination at this time revealed excellent healing. There was trabecular bone formation and the radiolucent area was considerably smaller.

The option for root canal obturation was made. Mineral trioxide aggregate (MTA; Dentsply-Maillefer, Ballaigues, Switzerland) was used to provide an apical plug and avoid extrusion of the root fillings (Fig. 3). Hardness of the apical plug was checked after 2 weeks and the canal was obturated with thermoplasticized gutta-percha and an endodontic sealer (Fig. 4).

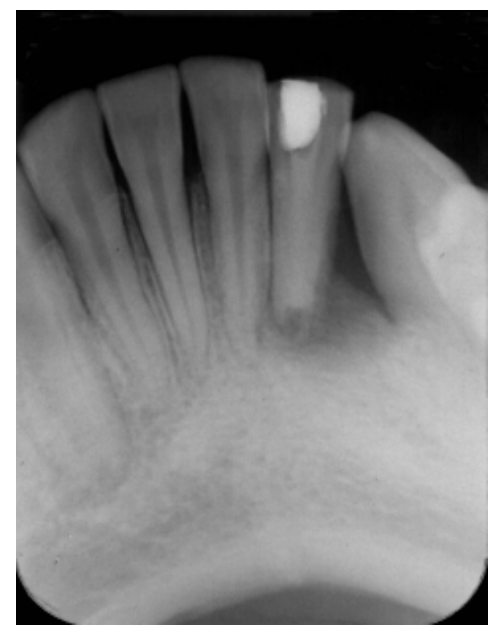

Figure 2. Radiograph showing intracanal dressing with calcium hydroxide.

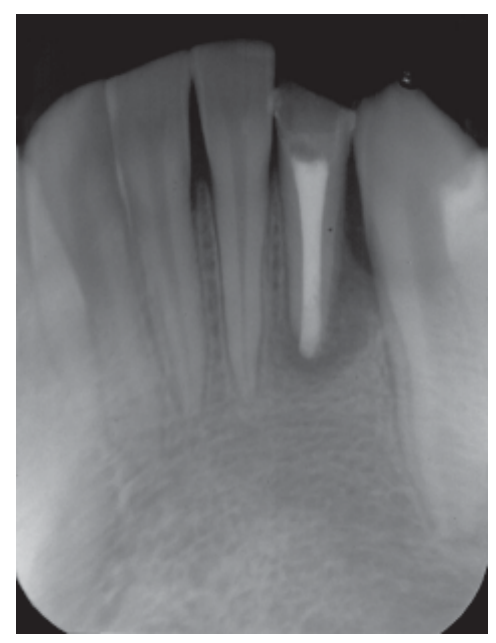

Figure 4. Post obturation radiograph, final result. 
Two-year follow-up radiographs showed decrease of the radiolucent area and healing of the periapical tissues. Although a vertical bone defect is observed radiographically, the lateral incisor was clinically asymptomatic without mobility (Fig. 5).

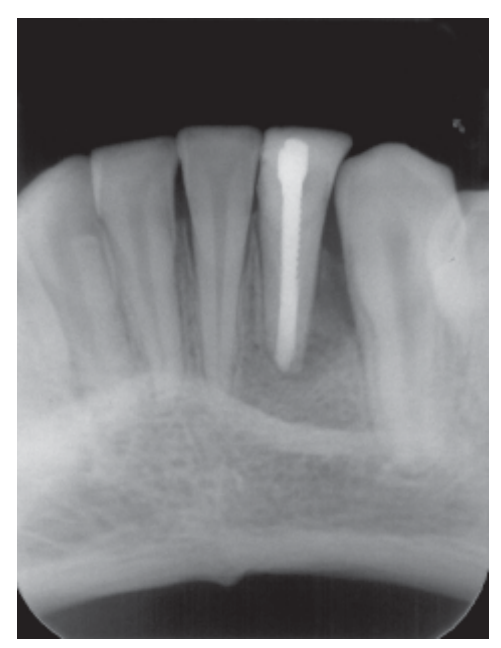

Figure 5. 24-month follow-up radiograph.

\section{DISCUSSION}

Necrotic pulp provides nutrients for pathogenic bacteria to grow and form a periapical lesion (5). The diagnosis of pulp necrosis should be based on clinical findings such as changes in tooth color, absence of sensitivity to thermal or electrical stimuli, presence of sinus tract or radiographic periapical inflammatory changes (6). In the case hereby reported, clinical and radiographic signs indicated pulp necrosis.

The primary goal of endodontic therapy is to reduce microorganisms to a minimum and remove irritants and necrotic tissue from the root canal system. In that way, mechanical instrumentation is allied to copious irrigation with antimicrobial solutions capable of dissolving organic tissue.

Apexification is aimed at the formation of a mineralized barrier in the root apex in such a way that gutta-percha can be condensed properly in the main canal space (2). Calcium hydroxide has been extensively used to accomplish apical closure due to its apparent ability to stimulate hard tissue formation (7). However, the use of calcium hydroxide in these cases presents some disadvantages such as the extended time required to form the mineralized barrier (8). In spite of this, treatment with calcium hydroxide has resulted in complete periapical healing, or in dramatic reduction of periapical lesions, especially in young patients, within 1 to 3 months after treatment (5). Healing was observed as early as 3 months after treatment in this case.

As soon as the periapical lesion showed some reduction in size, an apical plug of 3 to $5 \mathrm{~mm}$ of MTA was placed at the apex to avoid overflow of the obturating materials. Mineral trioxide aggregate has been considered an excellent root-end filling material as it provides good sealing ability and is biocompatible to periapical tissues, being considered the only effective material able to create an artificial apical seal of incomplete root apices (4). MTA is also known for its excellent biological properties and low citotoxicity allowing adequate healing of the periapical tissues (9).

In the case reported in this paper, non-surgical, conventional root canal treatment was successful in healing a large periapical lesion. Several factors such as the removal of pathogenic bacteria from the root canal, intracanal dressing with calcium hydroxide and rootend filling with MTA contributed to the success of the treatment.

\section{RESUMO}

O presente relato descreve o tratamento de uma fratura coronária severa em um incisivo inferior esquerdo de ápice incompletamente formado, em um paciente de 12 anos de idade indicado ao Centro de Traumatologia Dental da Universidade Unigranrio. Após os procedimentos endodônticos convencionais e medicação intracanal com pasta de hidróxido de cálcio, foi realizado um tampão apical com agregado de trióxido mineral na tentativa de evitar um extravasamento de guta-percha e cimento endodôntico para os tecidos periapicais. Após 2 anos de proservação, o dente se encontrava assintomático e o exame radiográfico mostrou o reparo completo da lesão apical.

\section{REFERENCES}

1. Habert H. One-step apexification without calcium hydroxide. J Endod 1996;22:690-692.

2. Weisenseel J, Hicks L, Pelleu G. Calcium hydroxide as an apical barrier. J Endod 1987;13:1-5.

3. Maroto M, Barberia E, Planells P, Vera V. Treatment of a non-vital immature incisor with mineral trioxide aggregate (MTA). Dent Traumatol 2003;19:165-169.

4. Hayashi M, Shimizu A, Ebisu S. MTA for obturation of mandibular central incisors with open apices: case report. J Endod 2004;30:120-122.

5. Öztan M. Endodontic treatment of teeth associated with a large periapical lesion. Int Endod J 2002;35:73-78. 
6. Çalskan M, Türkün M. Periapical repair and apical closure of a pulpless tooth using calcium hydroxide. Oral Surg Oral Med Oral Pathol Oral Radiol Endod 1997;84:683-687.

7. Ghose LJ, Baghdady VS, Hikmat BYM. Apexification of immature apices of pulpless permanent anterior teeth with calcium hydroxide. J Endod 1987;13:285-290.

8. Hachmeister DR, Schindler WG, Walker WA 3rd, Thomas
DD. The sealing ability and retention characteristics of mineral trioxide aggregate in a model of apexification. J Endod 2002;28:386-390.

9. Bernabé PFE, Holland R, Morandi R, Souza V, Nery MJ, Otoboni Filho JA, Dezan Junior E, Gomes-Filho JE. Comparative study of MTA and other materials in retrofilling of pulpless dogs' teeth. Braz Dent J 2005;16:149-155.

Accepted May 30, 2005 